\title{
Analisis Pembubaran Ormas Tanpa Proses Peradilan Pasca Penetapan UU No. 16 Tahun 2017 Tentang Ormas
}

\author{
Nur Aji Pratama ${ }^{1}$ \\ ${ }^{1}$ Fakultas Syariah, IAIN Jember.E-mail: ajimas528@gmail.com
}

\begin{tabular}{|c|c|}
\hline Article & Abstract \\
\hline $\begin{array}{l}\text { How to cite: } \\
\text { Nur Aji Pratama, 'Analisis } \\
\text { Pembubaran Ormas } \\
\text { Tanpa Proses Peradilan } \\
\text { Pasca Penetapan UU No. } \\
\text { 16 Tahun 2017 Tentang } \\
\text { Ormas' (2020) Vol. 1 No. } 2 \\
\text { Rechtenstudent Journal } \\
\text { Fakultas Syariah IAIN } \\
\text { Jember. } \\
\text { Histori artikel: } \\
\text { Submit } 11 \text { April 2020; } \\
\text { Diterima } 11 \text { Juli 2020; } \\
\text { Diterbitkan } 5 \text { Agustus } \\
\text { 2020. } \\
\text { ISSN: } \\
\text { 2723-0406 (media cetak) }\end{array}$ & 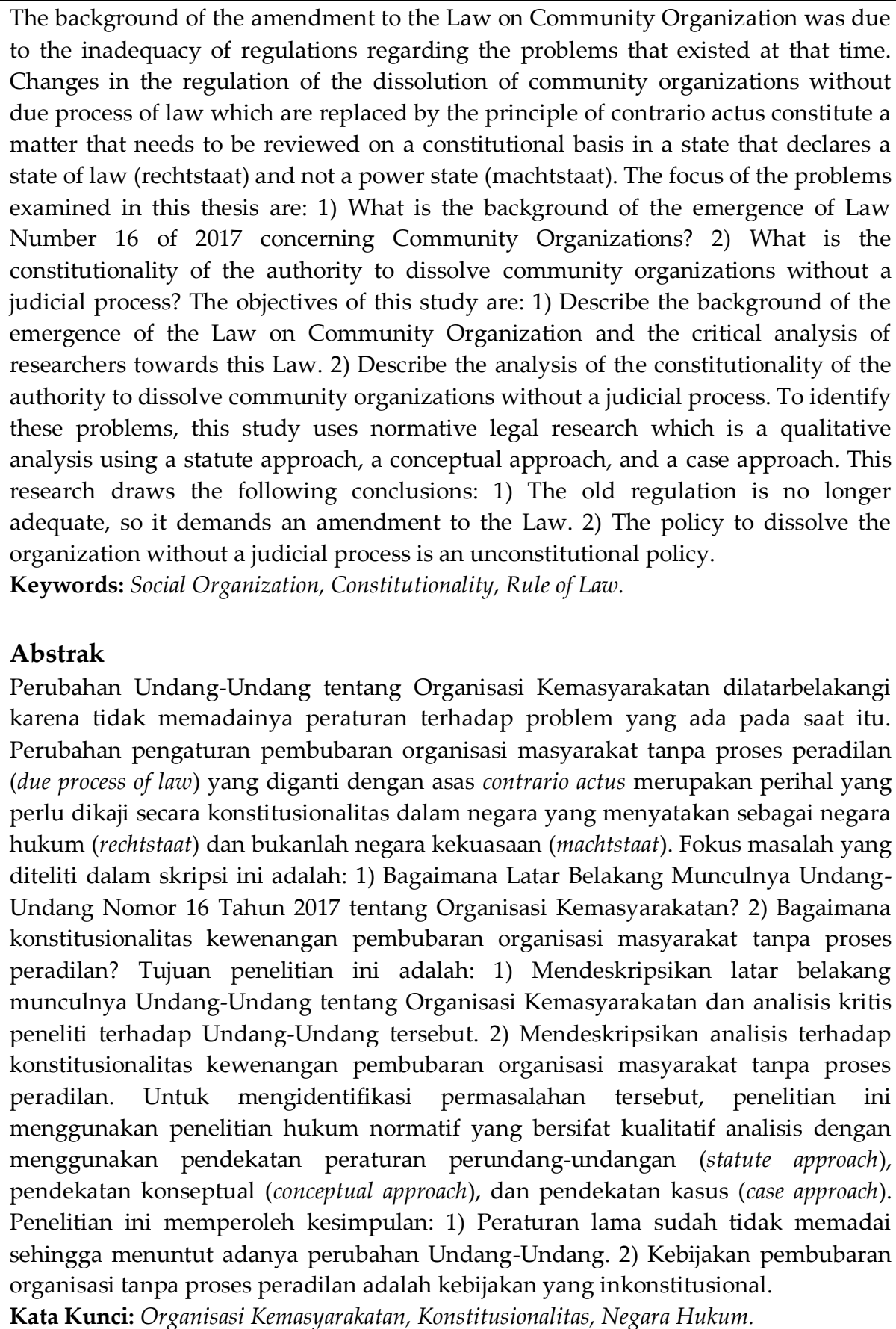 \\
\hline
\end{tabular}




\section{Pendahuluan}

Eksistensi Organisasi Kemasyarakatan (Ormas) dalam kehidupan bermasyarakat dan berbangsa merupakan bentuk komitmen Negara dalam menjalankan kebebasan berserikat dan berkumpul yang dijamin konstitusi. Negara mengharapkan Ormas dapat berpartisipasi mewujudkan tujuan dan kebijakan nasional dalam kerangka Negara Kesatuan Republik Indonesia yang berdasarkan Pancasila dan peraturan perundang-undangan. Hal ini merupakan pengejawantahan nilai-nilai demokrasi dalam suatu negara hukum. ${ }^{1}$

Kebijakan dengan menetapkan Undang-Undang Nomor 16 Tahun 2017 atas Perpu Nomor 2 Tahun 2017 Tentang Organisasi Kemasyarakatan merupakan serangkaian peristiwa hukum dalam perjalanan praktik hukum di negara Indonesia. Namun, dalam praktiknya Undang-Undang tersebut dinilai terdapat prinsip yang mencederai nilai-nilai konstitusi dan demokrasi yang ada di Indonesia.

Pemerintah melalui Menteri Koordinator Bidang Politik Hukum dan Keamanan (Menkopolhukam) Wiranto, pada 12 Mei 2017, menyatakan akan membubarkan ormas-ormas yang dinilai mengancam keutuhan Negara Kesatuan Republik Indonesia (NKRI). Hingga pada akhirnya salah satu ormas yang dikenal dengan Hizbut Tahrir Indonesia (HTI) secara resmi dibubarkan sesuai dengan mekanisme peraturan yang berlaku. Pemerintah menilai ormas tersebut berdasarkan pengamatan di lapangan dan melalui suatu proses pengawasan yang panjang dan mendetail, gerakan dakwah ormas HTI telah masuk ke ranah politik dan secara nyata mengancam kedaulatan NKRI, yakni "gerakan politik mengusung ideologi khilafah".

Sejak Presiden Joko Widodo menerbitkan Perpu Nomor 2 Tahun 2017 tentang Perubahan Undang-Undang Nomor 17 Tahun 2013 tentang Organisasi Kemasyarakatan, dan sekarang telah ditetapkan menjadi Undang-Undang No. 16 Tahun 2017 tentang Organisasi Kemasyarakatan, guncangan stabilitas sosial rentan terjadi. Hal ini dikarenakan UndangUndang tersebut terdapat banyak hal yang dinilai kontroversi. Seperti pemerintah tidak wajib mengikuti proses pengadilan dalam membubarkan suatu ormas. Hal ini dinilai oleh sebagian pakar hukum bertentangan dengan Pancasila dan Konstitusi. ${ }^{2}$

Salah satu norma krusial yang menjadi perdebatan dalam Perpu tersebut adalah kewenangan pembubaran Ormas oleh pemerintah sebagaimana diatur dalam Pasal 61 dan 62 ayat (3) dan Pasal 80 A Undang-Undang Nomor 16 Tahun 2017 Tentang Organisasi Kemasyarakatan. Pasal 62 ayat (3) mengatur, "Dalam hal Ormas tidak mematuhi sanksi penghentian kegiatan, menteri dan menteri yang menyelenggarakan urusan pemerintahan di bidang hukum dan hak asasi manusia sesuai dengan kewenangannya melakukan pencabutan surat keterangan terdaftar atau pencabutan status badan hukum." Sedangkan Pasal 80 A mengatur, "Pencabutan status badan hukum Ormas sebagaimana dimaksud dalam Pasal 61 ayat (1) huruf $\mathrm{c}$ dan ayat (3) huruf b sekaligus dinyatakan bubar berdasarkan Peraturan Pemerintah Pengganti Undang-Undang ini."

Pembubaran organisasi masyarakat berdasarkan Undang-Undang Nomor 16 Tahun 2017 dengan meniadakan peran pengadilan, perlu dikaji dan dianalisis lebih mendalam. Karena keberadaan organisasi masyarakat di Indonesia sebagai manifestasi dari hak kemerdekaan berserikat dan berkumpul yang dijamin oleh konstitusi. Esensi ormas

${ }^{1}$ Jurnal Penelitian Hukum, Politik Hukum Dan Konstitusionalitas Kewenangan Pembubaran Organisasi Kemasyarakatan, Berbadan Hukum Oleh Pemerintah. No: 30/E/KPT/2018, 446.

${ }^{2}$ Andhi Setya Budi dkk, Kedudukan Undang-Undang Keormasan Terhadap Kehidupan Berdemokrasi Di Indonesia, 43. 
didasarkan pada prinsip yang diatur dalam pasal 28E ayat 3 UUD 1945 haruslah ditegakkan dalam negara hukum, terlebih dalam hal pembubaran ormas maka harus sesuai dengan prinsip negara hukum yang demokratis. Salah satu elemen penting dalam negara hukum adalah adanya peradilan yang bebas dan tidak memihak.

Setiap negara hukum yang menganut tipe Anglo Saxon maupun Eropa Kontinental selalu memiliki "kekuasaan kehakiman yang bebas dan merdeka" sebagai sarana perlindungan hukum bagi warganya. Indonesia sebagai negara hukum ditegaskan dalam Pasal 1 ayat (3) Undang-Undang Dasar Negara Republik Indonesia Tahun 1945 (UUD Negara RI 1945) menjelaskan bahwa negara Indonesia adalah negara hukum. Hal itu menunjukan pengakuan yang tegas dan kuat dalam sistem hukum Indonesia. ${ }^{3}$

Berdasarkan dari penjelasan-penjelasan di atas, terdapat poin penting yang akan dikaji oleh peneliti, yakni terkait dengan konsep negara hukum yang selalu menjunjung tinggi prinsip-prinsip sebagai ciri khas bahwa negara tersebut merupakan negara hukum, salah satunya dengan menjunjung tinggi asas "due process of law" sebagai bentuk pengejawantahan keadilan sesungguhnya, namun dalam materi Undang-Undang No. 16 Tahun 2017 tentang Organisasi Kemasyarakatan, sudah menghapuskan sistem peradilan dalam pembubaran organisasi masyarakat. Selain itu, dalam menjunjung tinggi nilai keadilan dalam masyarakat, sistem peradilan melalui mekanisme upaya hukum yang telah di atur dalam peraturan perundang-undangan menjadi alat untuk mewujudkan nilai keadilan, namun nyatanya dalam Undang-Undang organisasi masyarakat tersebut menerapkan asas "contrario actus", yakni pencabutan oleh pihak yang mengeluarkan keterangan terdaftar terhadap suatu ormas menjadi mekanisme yang legal. Pembubaran secara sepihak tanpa ada perlawanan dalam pembuktian menyebabkan polemik dan kegaduhan dalam masyarakat.

Berdasarkan hal tersebut, terdapat isu hukum yang akan dikaji oleh peneliti, yakni 1) Bagaimana latar belakang munculnya Undang-Undang tentang organisasi masyarakat, 2) Bagaimana konstitusionalitas pembubaran organisasi masyarakat dalam Undang-Undang Nomor 16 Tahun 2017 tentang Organisasi Kemasyarakatan menurut UUD NRI Tahun 1945 dan Negara Hukum.

\section{Rumusan Masalah}

Adapun permasalahan yang diangkat menjadi pokok masalah sebagai berikut :

1. Bagaimana Kedudukan Undang-Undang Nomor 16 Tahun 2017 Tentang Penetapan Peraturan Pemerintah Pengganti Undang-Undang Nomor 2 Tahun 2017 Tentang Perubahan Atas Undang-Undang Nomor 17 Tahun 2013 Tentang Organisasi Kemasyarakatan Dalam Negara Demokrasi Indonesia?

2. Bagaimana Konstitutionalitas Pembubaran Organisasi Masyarakat Tanpa Proses Peradilan Pasca Penetapan Undang-Undang Nomor 16 Tahun 2017 Tentang Organisasi Kemasyarakatan Dalam Kajian UUD 1945 Dan Teori Negara Hukum?

\section{Metode Penelitian}

Pendekatan penelitian ini menggunakan penelitian hukum kualitatif, yaitu metode penelitian hukum dengan menganalisis masalah hukum terhadap isu hukum berdasarkan kajian normatif dan teori hukum. Pola pendekatan penelitian menggunakan pendekatan peraturan perundang-undangan (statute approach), pendekatan konseptual (conceptual

\footnotetext{
${ }^{3}$ Yuslim, Hukum Acara Peradilan Tata Usaha Negara, (Jakarta: Sinar grafika, 2015), 9.
} 
approach), dan pendekatan kasus (case approach) ${ }^{4}$. Jenis penelitian ini adalah penelitian pustaka (library research), yaitu penelitian dalam teori atau filsafat hukum, penelitian hukum dalam level dogmatik hukum atau penelitian untuk keperluan praktek hukum. ${ }^{5}$

Teknik pengumpulan data dilakukan dengan cara penelitian kepustakaan (library research) terhadap bahan hukum primer yakni Undang-Undang Nomor 16 Tahun 2017 Tentang Penetapan Peraturan Pemerintah Pengganti Undang-Undang Nomor 2 Tahun 2017 Tentang Perubahan Atas Undang-Undang Nomor 17 Tahun 2013 Tentang Organisasi Kemasyarakatan, serta bahan hukum sekunder dari buku, jurnal, laporan, dan artikel cetak maupun elektronik berkaitan dengan konsep-konsep dan kajian kewenangan pembubaran Ormas.

Analisa data adalah proses pengorganisasian data ke dalam pola, kategori dan satuan uraian dasar sehingga dapat ditemukan tema dan dapat merumuskan reflektif deskriptif dengan teknik content analysis seperti yang diuraikan dapat dirumuskan hipotesis yang diuraikan data. ${ }^{6}$

\section{Hasil dan Pembahasan}

\section{Latar Belakang Munculnya Undang-Undang Nomor 16 Tahun 2017 Tentang Organisasi Kemasyarakatan}

Dalam perspektif politik hukum, menyatakan bahwa "hukum merupakan produk politik" adalah benar jika didasarkan pada das sein dengan mengonsep hukum sebagai Undang-Undang. ${ }^{7}$ Hal ini senada dengan pandangan peneliti terkait dengan latar belakang munculnya Undang-Undang Nomor 16 Tahun 2017 Tentang Organisasi Kemasyarakatan. Undang-Undang Nomor 16 Tahun 2017 Tentang Organisasi Kemasyarakatan merupakan produk hukum yang disahkan oleh Lembaga Legislatif (DPR RI) dari Peraturan Pemerintah Pengganti Undang-Undang (Perpu) yang dikeluarkan oleh Presiden Joko Widodo. Peraturan Pemerintah Pengganti Undang-Undang (Perpu) juga merupakan produk hukum yang diakui dalam tata hukum dan hierarki peraturan perundang-undangan yang sejajar dengan UndangUndang. Penjelasan tersebut dapat dilihat dalam Pasal 7 ayat (1) Undang-Undang Nomor 15 Tahun 2019 Tentang Perubahan Atas Undang-Undang Nomor 12 Tahun 2011 Tentang Pembentukan Peraturan Perundang-Undangan, dijelaskan bahwa jenis dan hierarki perundang-undangan terdiri atas Undang-Undang Dasar Negara Republik Indonesia Tahun 1945 sebagai tata urutan tertinggi, Ketetapan Majelis Permusyawaratan Rakyat sebagai urutan kedua, Undang-Undang/Peraturan Pemerintah Pengganti Undang-Undang (Perpu), dan beberapa peraturan perundang-undangan di bawahnya.

Berdasarkan hierarki yang dijelaskan dalam pasal 7 ayat (1) Undang-Undang Nomor 15 Tahun 2019 Tentang Perubahan Atas Undang-Undang Nomor 12 Tahun 2011 Tentang Pembentukan Peraturan Perundang-Undangan sudah jelas bahwa Undang-Undang dengan Peraturan Pemerintah Pengganti Undang-Undang (Perpu) adalah sejajar. Poin perbedaan antara keduanya adalah terkait dengan syarat dan prosedural dikeluarkannya produk hukum tersebut sehingga sangat mempengaruhi pada keabsahan produk hukum tersebut. Secara teori Undang-Undang dikeluarkan dengan dasar persetujuan Dewan Perwakilan Rakyat

\footnotetext{
${ }^{4}$ Peter Mahmud Marzuki, Penelitian Hukum, (Jakarta: Kencana), 2017, 133.

${ }^{5}$ Peter Mahmud Marzuki, Penelitian Hukum, 96

${ }^{6}$ Lexy Meleong, Metodologi Penelitian Kualitatif, 2

${ }^{7}$ Moh. Mahfud MD, Politik Hukum di Indonesia, 5.
} 
(DPR) dan Presiden, sedangkan Peraturan Pemerintah Pengganti Undang-Undang (Perpu) dikeluarkan serta merta oleh presiden dengan dasar hal ihwal kegentingan yang memaksa, yang mana sampai saat ini pun kegentingan yang memaksa masih menjadi subyektifitas presiden.

Dalam konstitusi UUD 1945, terdapat pengaturan terkait dengan dikeluarkannya Peraturan Pemerintah Pengganti Undang-Undang (Perpu), yakni termaktub dalam Pasal 12 dan Pasal 22, dijelaskan bahwa presiden harus menyatakan keadaan bahaya. Syarat dan akibatnya keadaan bahaya dijelaskan dalam Undang-Undang, sedangkan dalam Pasal 22 UUD 1945 dijelaskan, khususnya pada ayat (1), "Dalam hal ihwal kegentingan yang memaksa, Presiden berhak menetapkan peraturan pemerintah sebagai pengganti Undang-Undang (Perpu)" ${ }^{8}$

Peraturan Pemerintah Pengganti Undang-Undang (Perpu) Nomor 2 Tahun 2017 Tentang Perubahan Atas Undang-Undang Nomor 17 Tahun 2013 Tentang Organisasi Kemasyarakatan dikeluarkan oleh pemerintah pada tanggal 10 Juli 2017. Ada beberapa argumen tentang terbitnya Peraturan Pemerintah Pengganti Undang-Undang (Perpu) Nomor 2 Tahun 2017 tentang Organisasi Kemasyarakatan, yang poin pokoknya adalah: ${ }^{9}$

a. Perpu tersebut diterbitkan dalam rangka tugas dan komitmen pemerintah untuk melindungi segenap bangsa dan tumpah darah Indonesia;

b. Organisasi kemasyarakatan di Indonesia yang saat ini mencapai 344.039 Ormas, yang telah beraktivitas di segala bidang kehidupan, baik dalam tingkat nasional, maupun di tingkat daerah, harus diberdayakan dan dibina. Sehingga mampu memberikan kontribusi positif bagi pembangunan nasional;

c. Kenyataannya saat ini, terdapat kegiatan-kegiatan ormas yang bertentangan dengan pancasila dan Undang-Undang Dasar Negara Republik Indonesia 1945, yang merupakan ancaman terhadap eksistensi bangsa dengan telah menimbulkan konflik di masyarakat.

d. UU Nomor 17 Tahun 2013 tentang Organisasi Kemasyarakatan tidak lagi memadai sebagai sarana untuk mencegah dan menyelesaikan meluasnya ideologi yang bertentangan dengan Pancasila dan UUD NRI 1945, baik dari aspek substantif terkait dengan norma, larangan dan sanksi serta prosedur hukum yang ada. Antara lain, tidak terwadahinya asas hukum administrasi contrario actus yaitu asas hukum bahwa lembaga yang mengeluarkan izin atau yang memberikan pengesahan adalah lembaga yang seharusnya mempunyai wewenang untuk mencabut atau membatalkannya;

e. Selama ini, pengertian tentang ajaran dan tindakan yang bertentangan dengan pancasila dirumuskan secara sempit yaitu hanya sebatas pada ajaran Atheisme, Marxisme, dan Linisisme, padahal sejarah Indonesia membuktikan bahwa ajaran-ajaran lain yang terdapat dalam bingkai sosial masyarakat juga bisa dan bertentangan dengan Pancasila.

Berdasarkan argumentasi tersebut, menjadikan Undang-Undang Nomor 16 Tahun 2017 tentang Organisasi Kemasyarakatan sebagai payung hukum bagi pemerintah untuk membubarkan organisasi masyarakat yang memiliki potensi bertentangan secara ideologi dengan Pancasila dan UUD NKRI 1945 dalam rangka memberdayakan dan membina

\footnotetext{
${ }^{8}$ I Gede Pantja Astawa, Suprin Naa, Dinamika Hukum dan Ilmu Perundang-Undangan di Indonesia, (Bandung, P.T ALUMNI, 2012), 62.

9 Sudjito, Membaca "Kepentingan Politik" di balik Perpu ormas dan Impilkasi sosiologisnya pada masyarakat, makalah dalam seminar nasional: QUO VADIS PERPPU ORMAS, diselenggarakan oleh FH UII, R.Sidang utama Lt. 3, hlm. 1
} 
organisasi masyarakat agar mampu berkontribusi positif dalam pembangunan nasional. Selain itu, dalam Perpu ormas tersebut juga menambahkan sistem pembubaran berdasarkan asas cotrario actus, yaitu yang memberikan izin dan mengesahkan ormas itu juga diberikan hak untuk mencabut izin ormas yang bersangkutan.

Selain argumentasi di atas, pemerintah juga menjelaskan adanya 3 (tiga) pertimbangan pemerintah dalam penerbitan Perpu ormas hingga akhirnya disahkan menjadi UU tentang organisasi Kemasyarakatan. Pertama, menjadi hal yang wajar bagi pemerintah untuk mengeluarkan Perpu ormas, karena hal tersebut merupakan hak prerogatif pemerintah yang dijamin dalam konstitusi NKRI. Kedua, dalam rangka memberikan solusi atas UU Nomor 17 Tahun 2017 yang belum memadai, agar tidak terjadi kekosongan hukum. Ketiga, dikeluarkan Perpu Ormas karena payung hukum sebagai legalitas dirasa tidak mampu menjawab persoalan hukum pada saat itu, dan apabila membuat Undang-Undang pun dibutuhkan waktu yang sangat lama, oleh karena itu Perpu ormas diterbitkan dan sahkan menjadi UU Nomor 16 Tahun 2017 Tentang Organisasi Kemasyarakatan. Payung hukum tersebutlah berdasarkan argumentasi pemerintah hingga saat ini legalitas nya masih terus eksis dalam upaya pembubaran ormas yang bertentangan dengan Pancasila dan UUD NKRI 1945.

\section{Konstitusionalitas Pembubaran Organisasi Masyarakat Tanpa Proses Peradilan} Pasca Penetapan Undang-Undang Nomor 16 Tahun 2017 Tentang Organisasi Kemasyarakatan Dalam Kajian UUD 1945 dan Teori Negara Hukum

Setelah ditetapkannya Undang-Undang Nomor 16 Tahun 2017 tentang Organisasi Masyarakat tersebut, akhirnya Direktur Jenderal Administrasi Hukum Umum Kementerian Hukum dan HAM menerbitkan surat Keputusan Nomor AHU30.AH.01.08 Tahun 2017 tentang pencabutan Keputusan Kementerian Hukum dan HAM Nomor AHU-0028.60.10.2014 tentang Pengesahan Pendirian Badan Hukum Perkumpulan Hizbut Tahrir Indonesia (HTI) merupakan adanya fakta empiris pembubaran ormas berdasarkan aturan perubahan tersebut yakni pembubaran ormas tanpa proses peradilan. Pembahasan terkait dengan konstitutionalitas kewenangan pembubaran organisasi masyarakat tanpa proses peradilan yang diatur dalam Undang-Undang Nomor 16 tahun 2017 tentang Organisasi Masyarakat dirasa penting oleh peneliti dengan mempertimbangkan norma yang lebih rendah tidak boleh bertentangan dengan norma yang lebih tinggi agar terjaga harmonisasi di setiap tingkatan norma. Oleh karena itu, eksistensi Mahkamah Konstitusi dalam melaksanakan kewenangannya sangat berpengaruh terhadap sistem hukum dan ketatanegaraan di suatu negara. Hal ini selaras dengan pendapat Martin Shapiro yang menyatakan, the fact that judicial review not only managed to survive but even spreads to more system is important evidence its functionality influencing the policy processes. ${ }^{10}$ Pengaruh tersebut terutama pada kewenangan Mahkamah Konstitusi untuk melaksanakan pengujian konstitusionalitas Undang-Undang.

Kewenangan pengujian konstitusional (constitutional review) Undang-Undang terhadap Undang-Undang Dasar Republik Indonesia Tahun 1945 (UUD 1945) oleh Mahkamah Konstitusi didasarkan pada teori hierarki norma dalam pandangan Hans Kelsen yang menyatakan bahwa sistem hukum disusun secara berjenjang dan bertingkat-tingkat dengan hubungan super dan subordinasi dalam konteks spasial antara norma atasnya dan norma di

\footnotetext{
${ }^{10}$ Martin Shapiro, Alec Stone Sweet, On Law, Politics, and Judicializations, (New York, Oxford, 2002)., 145.
} 
bawahnya. ${ }^{11}$ Berdasarkan hal tersebut tidak boleh ada pertentangan antara norma yang lebih rendah kepada norma yang lebih tinggi demi terciptanya harmonisasi di setiap tingkatan hierarki norma. Kesesuaian norma sebagaimana yang disampaikan diatas, perlu menjadi perhatian karena berhubungan kekuatan mengikat (binding force) norma, Hans Kelsen menyatakan, to say that a norm is valid, is to say that we assume its existence or what amounts to the same thing we assume that it has "binding force" for those whose behavior it regulates. ${ }^{12}$ Oleh karenanya, ketika norma yang lebih rendah bertentangan dengan norma yang lebih tinggi, maka dapat dinyatakan batal dan tidak memiliki kekuatan mengikat (null and void).

Dengan ditetapkan Undang-Undang Nomor 16 tahun 2017 pada 22 November 2017 sebagai bentuk pengesahan Perpu Nomor 2 Tahun 2017 Tentang Organisasi Kemasyarakatan, yang dalam Undang-Undang Nomor 16 Tahun 2017 seluruh pasal dalam Perpu Nomor 2 Tahun 2017 disahkan sebagaimana yang tercantum dalam lampiran Undang-Undang tersebut. Terfokus dengan penelitian ini adalah pengaturan kewenangan pembubaran organisasi masyarakat tanpa proses peradilan yang diatur dalam pasal 61 dan 62 ayat (3) dan pasal 80 A Undang-Undang Nomor 16 tahun 2017 Tentang Penetapan Peraturan Pemerintah Pengganti Undang-Undang Nomor 2 Tahun 2017 Tentang Perubahan Atas Undang-Undang Nomor 17 Tahun 2013 Tentang Organisasi Kemasyarakatan. Beberapa pasal tersebutlah yang akan peneliti uji konstitusinoalitasnya terhadap Undang-Undang Dasar Republik Indonesia (UUD) Tahun 1945.

Dalam membangun bangunan pemikiran terhadap penelitian ini, peneliti menggunakan argumentasi hukum/nalar hukum (legal reasoning) yaitu: konsep asas Due Process of Law dijelaskan dalam pasal 1 ayat (3) UUD 1945, dan Konsep asas Contrario Actus dalam pembubaran organisasi masyarakat berdasarkan UU Ormas.

Pertama, analisis konsep due process of law dalam negara hukum dilandaskan pada Pasal 1 ayat (3) UUD 1945 yang menegaskan bahwa, "Negara Indonesia adalah Negara Hukum". Negara Hukum dalam pemikiran A.V. Dicey disebut dengan "The Rule of Law" dengan menyebutkan tiga ciri penting yaitu Supremacy of Law, Equality before the Law, Due Process of Law. Selaras dengan pemikiran Jimly Asshidiqie yang dikembangkan dengan sebutan 12 prinsip Negara Hukum, yaitu Supremasi Hukum, Persamaan dalam Hukum, Asas Legalitas (Due Process of Law), Pembatasan Kekuasaan, Organ-Organ Eksekutif Independen, Peradilan Bebas dan Tidak Memihak, Peradilan Tata Usaha Negara, Perlindungan Hak Asasi Manusia, Bersifat Demokratis, Mewujudkan Tujuan Negara, Transparansi dan Kontrol Sosial. ${ }^{13}$ Selaras dengan pemikiran tersebut, Julius Stahl Mengatakan ada empat elemen penting yang harus ada dalam negara hukum yaitu, Perlindungan Hak Asasi Manusia, Pembagian Kekuasaan, Pemerintah Berdasarkan Undang-Undang, Dan Peradilan Tata Usaha Negara. Berdasarkan pemikiran tersebut, konsep due process of law dapat dimaknai sebagai bentuk penegakan hukum yang adil yang merupakan elemen penting dan beresensi dalam pelaksanaan konsep Negara Hukum. Argumentasi tersebut memberikan pandangan apabila konsep due process of law terlanggar, maka konsep negara hukum juga terlanggar.

Secara historis, istilah due process of law mulai dikenal diberbagai negara yang bermula di Inggris dengan lahirnya Magna Charta (1215) yang kemudian disusul dengan Bill of Rights

\footnotetext{
${ }^{11}$ Jimly Asshiddiqie, Konstitusi dan Konstitusionalisme Indonesia, (Jakarta, Konstitusi Press, 2010)., 110.

${ }^{12}$ Hans kelsen, General Theory of Law, (London, Oxford University Press, 1949)., 30

${ }^{13}$ Jimly Asshiddiqie, Konstitusi dan Konstitusionalisme Indonesia, 122-123.
} 
(1689), Declaration of Independen (1876) dan Declaration of Human Rights (1948). ${ }^{14}$ Konsep due process of law berasal dari English Common Law dalam Magna Charta yang merupakan kesepakatan pada tahun 1215 antara raja John dan rakyat kelas atas yaitu, "No free man shall be seized, or imprisoned, except by the lawful judgment of his peers, or by due process of law". Kesepakatan ini mendalilkan seseorang tidak boleh dihilangkan hak hidupnya, kebebasannya dan harta miliknya tanpa pemberitahuan dan kesempatan untuk membela hak-hak mereka. ${ }^{15}$

Sedangkan di Amerika Serikat, konsep ini dikembangkan Amandemen Konstitusi Amerika ke-14 yang diratifikasi pada tahun 1868 dengan menyatakan, "Nor Shall any state deprive any person of life, liberty, or property, without due process of law". Kata " "due" dalam hukum Amerika Serikat dimaknai dan dipahami sebagai reasonable (masuk akal), just (adil), dan proper (patut), kewenangan untuk menentukan adanya proses penegakan hukum yang reasonable, just, proper terletak pada pengadilan (the power to decide as to the reasonability of the same is vested in the courts).

Selain itu, terdapat pendapat due process of law dengan pemaknaan yang lebih luas, seperti yang ungkapkan oleh Jimly Asshidiqie yang mentranslasi makna due process of law sebagai asas legalitas dengan penjelasan bahwa segala tindakan pemerintah harus didasarkan pada peraturan perundang-undangan yang sah dan tertulis, peraturan tersebut harus ada dan berlaku lebih dulu dari pada tindakan atau perbuatan administrasi yang dilakukan, oleh karena itu segala suatu tindakan administrasi harus didasarkan pada aturan atau " "rules and prosedures" (regels). Pendapat ini memberikan pengertian bahwa penerapan due process of law tidak langsung dihubungkan dengan peran pengadilan, namun dalam penegakan hukum haruslah proporsional sesuai dengan tujuan ditegakkannya hukum dalam suatu negara sehingga urgensi penegakan hukum melalui proses peradilan harus lah selalu ada guna menjaga hak konstitusional warga negara dan menjaga kesewenang-wenangan penguasa terhadap warga negara.

Terdapat juga pandangan lain yang menghubungkan penerapan due process of law dengan peran pengadilan, seperti yang didefinisikan dalam Black Law Dictionary menjelaskan, Due Process of Law implies the right of the person affected thereby to be present before the tribunal which pronounces judgement upon the question of life, liberty or property, in its most comprehensive sense: to be heard, by testimony or otherwise, and to have the right of controverting, by proff, every material fact which bears on the question of right in the matter involve. If any question of fact or liability be conclusively presumed against him, this is no due process of law. ${ }^{16}$ Pendefinisian tersebut menjelaskan bahwa penegak hukum yang adil berarti memberikan hak kepada seseorang untuk hadir di hadapan pengadilan untuk memutuskan mengenai kehidupan, kebebasan, atau properti yang dimilikinya melalui hak untuk didengar kesaksiannya dan hak untuk membela dirinya berdasarkan bukti dari setiap dalil yang berkaitan dengan keterlibatannya.

Kemudian, Friedman menegaskan bahwa, prinsip due process of law yang melembaga dalam proses peradilan sudah ada sejak dua ratus tahun yang lampau, bahkan saat ini sudah melembaga diseluruh bidang kehidupan sosial. Begitu juga dengan Tobias dan Petersen yang menjelaskan bahwa due process of law merupakan, "constitutional guaranty, that no person will be deprived of live, liberty or property for reason that arbitrary actions of the government, which has

\footnotetext{
${ }^{14}$ Rahmat Efendi Al Amin Siregar, "Due Process of Law dalam Sistem Peradilan Pidana di Indonesia Kaitanya dengan Perlindungan HAM", Jurnal Ilmiah Fitrah, Vol. 1, 2015., 17.

${ }^{15}$ Atip Latipulhayat, "Due Process of Law", Jurnal Hukum Padjajaran, Vol. 4 No. 2, 2017., ii.

${ }^{16}$ Bryan A. Garner, Black"s Law Dictionary Ninth Edition, St. PaulMinn, West Publishing co, 2010, 603
} 
element: hearing, counsel, defence, evidence, and a fair and impartial court. ${ }^{17}$ Pendapat-pendapat tersebut dapat dijadikan landasan bahwa penerapan prinsip due process of law langsung berkaitan dengan peran peradilan, khususnya untuk melindungi hak konstitusional warga negara.

Selaras dengan pandangan tersebut, Atip Latipulhayat menyatakan bahwa due process of law merupakan jaminan konstitusional yang menjamin adanya proses hukum yang adil dan memberikan kesempatan kepada seseorang untuk mengetahui proses tersebut dan kesempatan untuk didengar keterangannya, mengapa hak hidup, kebebasan dan harta miliknya dirampas atau dihilangkan. Oleh karena itu pandangan tersebut mendalilkan bahwa prinsip due process of law menjamin penegakan hukum akan ditegakkan secara rasional sesuai dengan konstitusi guna menghindari tindakan sewenang-wenang penguasa terhadap warga negara. ${ }^{18}$

Argumentasi peneliti dengan menggunakan Conceptual Approach tersebut diatas, menegaskan urgensinya proses peradilan dalam segala bentuk problem sosial masyarakat, demi menjaga hak konstitusional warga negara. Pada beberapa pasal yang peneliti sebutkan diatas, terfokus pada pembubaran organisasi masyarakat tanpa proses peradilan yang dijelaskan dalam pasal 61, 62 ayat (3) dan pasal 80 A Undang-Undang Nomor 16 Tahun 2017 Tentang Penetapan Peraturan Pemerintah Pengganti Undang-Undang Nomor 2 Tahun 2017 Tentang Perubahan Atas Undang-Undang Nomor 17 Tahun 2013 Tentang Organisasi Kemasyarakatan memungkinkan pemerintah secara sepihak mencabut status badan hukum organisasi masyarakat tanpa didahului pemeriksaan di pengadilan. Sehingga peniadaan prinsip due process of law dalam pembubaran organisasi masyarakat tentunya terkesan akan lebih mengarah pada pemerintahan yang diktator dan bertentangan dengan pasal 1 ayat (3) UUD 1945. Didasarkan pada argument bahwa salah satu ciri negara hukum adalah pembatasan kekuasaan dan penyelenggaraan kekuasaan negara.

Ketentuan pengaturan pembubaran organisasi masyarakat pada pasal 61, 62 ayat (3) dan pasal 80 A Undang-Undang Nomor 16 tahun 2017 tentang organisasi kemasyarakatan merupakan sebuah langkah kemunduran dalam pembubaran organisasi masyarakat. Karena dalam regulasi tersebut menghilangkan prinsip due process of law dan pembagian kekuasaan. Hal tersebut dapat diketahui karena dalam regulasi tersebut kewenangan eksekutif memonopoli semua mekanisme dalam pembubaran organisasi masyarakat. Hal tersebut tentunya menjadi perhatian dan perlu ada kebijakan lagi yang lebih elegan dan proporsional. Pembatasan kekuasaan dalam penyelenggaraan kekuasaan negara mutlak sangat diperlukan, karena apabila fungsi kekuasaan negara terpusat dan terkonsentrasi pada satu tangan saja, maka sangat berpotensi untuk bertindak sewenang-wenang dan berkecenderungan menindas hak-hak warga negara. Lord Acton, seorang ahli sejarah inggris, yang juga dikutip oleh Miriam Budiardjo menyebutkan, "manusia yang mempunyai kekuasaan cenderung untuk menyalahgunakan kekuasaannya, tetapi manusia yang memiliki kekuasaan absolut akan menyalahgunakan kekuasaannya secara absolut (power tends to corrupt, but absolute power corrupt absolutely)..$^{19}$

\footnotetext{
17 Mardjono Reksodiputro, Hak Asasi Manusia Dalam Peradilan Pidana, (Jakarta, Pusat Pelayanan Keadilan dan Pengabdian Hukum, 1994)., 27

${ }^{18}$ Atip Latipulhayat, “Due Process of Law”, Jurnal Hukum Padjajaran, Vol. 4 No. 2, 2017.,ii

${ }^{19}$ Miriam Budiarjo, Dasar-Dasar Ilmu Politik, (Jakarta, PT. Gramedia Pustaka Utama, 2008)., 107
} 
Organisasi masyarakat sebagai instrument penting yang berperan dalam penyelenggaraan negara demokrasi, pembekuan dan pembubarannya haruslah didasarkan pada prinsip due process of law oleh pengadilan yang independen. Proses hukum dengan prinsip due proses of law ini menjadi penting dalam pembubaran organisasi masyarakat, karena pembubaran yang dilakukan oleh eksekutif secara sendiri sangat berpotensi menimbulkan kesewenang-wenangan sebagaimana yang terjadi dalam pemerintahan orde lama dan orde baru. Selain itu, dikhawatirkan juga pemerintah melakukan pembubaran organisasi masyarakat tanpa disertai bukti, saksi, dan suatu keputusan yang adil dan berimbang. Hal ini tentunya bertentangan dengan pasal $28 \mathrm{E}$ ayat (3) yang menyebutkan setiap orang berhak atas kebebasan berserikat, berkumpul dan mengeluarkan pendapat. Oleh karena itu, substansi dari aturan norma pembubaran organisasi masyarakat dalam Undang-Undang Nomor 16 Tahun 2017 Tentang Organisasi kemasyarakatan berkarakter represif dan ortodoks. ${ }^{20}$

Dengan adanya mekanisme kontrol melalui gugatan ke Pengadilan Tata Usaha Negara tidak mencegah pemerintah untuk membubarkan organisasi masyarakat secara sepihak sampai ada pengajuan gugatan ke Pengadilan tata Usaha negara hingga putusan hakim yang telah berkekuatan hukum tetap, karenanya sebelum adanya putusan hakim yang berkekuatan hukum tetap maka surat keputusan pemerintah tentang pembubaran organisasi masyarakat tersebut yang berlaku. Konsekuensi hukum nya adalah semua kegiatan dan atribut organisasi masyarakat tersebut dilarang sampai adanya putusan pengadilan yang berkekuatan hukum tetap yang diperkirakan proses tersebut akan memakan waktu lama karena pihak yang kalah menggunakan instrument banding/upaya hukum sampai dengan kasasi, proses adjukasi tersebut yang lama menimbulkan kerugian konstitusional warga negara karena tidak bisa menggunakan haknya sampai ada putusan pengadilan yang berkekuatan hukum tetap.

Hal terebut juga diperkuat dengan putusan Mahkamah Konstitusi No 6-13-20/PUUVIII/2010 yang menegaskan dalam konsiderannya bahwa tindakan perampasan atau pembatasan terhadap kebebasan sipil dalam bentuk pelarangan, yang dilakukan secara absolut oleh pemerintah, tanpa proses peradilan merupakan ciri tindakan negara kekuasaan (machtstaat) bukan negara hukum yang tegaskan dalam konstitusi UUD 1945 Pasal 1 ayat (3) bahwa negara Indonesia adalah negara hukum. Dikatakan oleh Mahkamah Konstitusi juga, tindakan pelarangan atau pembatasan terhadap suatu kebebasan sipil, "terutama tanpa melalui proses peradilan, merupakan suatu eksekusi tanpa peradilan (extra judicial execution) yang sangat ditentang dalam suatu negara hukum yang menghendaki due process of law. Due process of law seperti dipertimbangkan diatas adalah penegakan hukum melalui suatu sistem peradilan". ${ }^{21}$

Kedua, pengimplementasian asas contrario actus dalam pembubaran organisasi masyarakat berdasarkan Undang-Undang Nomor 16 Tahun 2017 Tentang Organisasi Kemasyarakatan bukanlah hal yang tepat. Merujuk pada konsideran putusan Mahkamah Konstitusi No 6-13-20/PUU-VIII/2010 bahwa peniadaan proses peradilan (due process of law) bukan lah ciri negara hukum (rechtstaat) melainkan ciri negara kekuasaan (machtstaat). Adanya peluang gugatan melalui Pengadilan Tata Usaha Negara, mekanisme ini hanya akan menguji prosedur teknis semata, bahwa pejabat Tata Usaha Negara telah bertindak berdasarkan amanat Undang-Undang. Yang dimaksud dengan asas contrario actus adalah di mana lembaga

\footnotetext{
${ }^{20}$ Moh. Mahfud MD. Politik Hukum di Indonesia, 7.

${ }^{21}$ Putusan Mahkamah Konstitusi 6-3-20/PUU-VIII/2010 tentang Pengujian Undang-Undang Nomor 16 Tahun 2004 tentang Kejaksaan Republik Indonesia dan Undang-Undang Nomor 4/PNPS/1963 tentang Pengamanan Terhadap Barang-Barang Cetakan yang Mengganggu Ketertiban Umum., 7
} 
yang mengeluarkan izin atau yang memberikan pengesahan mempunyai wewenang untuk mencabut dan membatalkannya. ${ }^{22}$ Dalam perihal pembubaran organisasi masyarakat diwakili Kementerian Hukum dan HAM yang dapat membubarkan organisasi masyarakat secara sepihak tanpa proses peradilan. Hal tersebut menurut peneliti perlu dikritik, karena pendaftaran organisasi masyarakat itu dalam bentuk pengesahan bukan izin. Hal tersebut sepemikiran dengan pandangan ahli tata negara, Mustafa Fakhri S.H., M.H.,LL.M bahwa penerapan asas contrario actus pada pembubaran organisasi masyarakat menunjukan bahwa pemerintah tidak memahami mengenai diferensiasi antara izin dan pengesahan. Dalam hal pemberian izin, pemberi izin memang dapat serta merta mencabut izin tersebut dengan syarat tertentu, namun untuk pengesahan, bahwa instansi yang mengesahkan tidak dapat begitu saja mencabutnya, kecuali ada syarat formal yang dapat membatalkan pengesahan tersebut. Penerapan asas contrario actus jika dimaknai sesuai dengan diatas, maka pemerintah juga berwenang untuk membubarkan seluruh bentuk apa saja yang butuh pengesahan dari pemerintah seperti yayasan dan partai politik.

Penerapan asas contrario actus dalam pembubaran organisasi masyarakat memang menimbulkan kegaduhan publik baik akademisi, politisi, praktisi dan masyarakat, karena kebijakan tersebut memunculkan disparitas antar konsep negara Indonesia dengan praktik hukum yang berlaku. Sehingga peneliti memandang bahwa mekanisme pembubaran organisasi masyarakat dengan hadirnya Undang-Undang Nomor 16 Tahun 2017 Tentang Organisasi Kemasyarakatan bukanlah tindakan solutif yang mampu menunaikan tugas hukum dalam masyarakat. Sebagaimana analisa yang digunakan peneliti dengan doktrin konsep yang ditawarkan oleh Lawrence M. Friedmen bahwa hukum dikatakan baik apabila memenuhi 3 unsur, yaitu struktur hukum (struktur of law), substansi hukum (substance of the law), budaya hukum (legal culture). Apabila dalam suatu negara ketiga unsur tersebut baik, maka sistem hukum yang berlaku dalam suatu negara pasti juga baik.

\section{Kesimpulan}

Peraturan Pemerintah Pengganti Undang-Undang (Perpu) Nomor 2 Tahun 2017 Tentang Perubahan Atas Undang-Undang Nomor 17 Tahun 2013 Tentang Organisasi Kemasyarakatan dikeluarkan oleh pemerintah pada tanggal 10 Juli 2017. Ada beberapa argumen tentang terbitnya Peraturan Pemerintah Pengganti Undang-Undang (Perpu) Nomor 2 Tahun 2017 Tentang Organisasi Kemasyarakatan, yang poin pokoknya adalah:

a. Perpu tersebut diterbitkan dalam rangka tugas dan komitmen pemerintah untuk melindungi segenap bangsa dan tumpah darah Indonesia;

b. Organisasi kemasyarakatan di Indonesia yang saat ini mencapai 344.039 Ormas, yang telah beraktivitas di segala bidang kehidupan, baik dalam tingkat nasional, maupun di tingkat daerah, harus diberdayakan dan dibina. Sehingga mampu memberikan kontribusi positif bagi pembangunan nasional;

c. Kenyataannya saat ini, terdapat kegiatan-kegiatan ormas yang bertentangan dengan Pancasila dan Undang-Undang Dasar Negara Republik Indonesia 1945, yang merupakan ancaman terhadap eksistensi bangsa dengan telah menimbulkan konflik di masyarakat.

\footnotetext{
${ }^{22}$ Bambang Arwanto, "Perlindungan Hukum Bagi Rakyat Akibat Tindakan Faktual Pemerintah", Jurnal Yuridika, Vol. 31 No. 3 September 2016., 367
} 
d. UU Nomor 17 Tahun 2013 tentang Organisasi Kemasyarakatan tidak lagi memadai sebagai sarana untuk mencegah dan menyelesaikan meluasnya ideologi yang bertentangan dengan Pancasila dan UUD NRI 1945, baik dari aspek substantif terkait dengan norma, larangan dan sanksi serta prosedur hukum yang ada. Antara lain, tidak terwadahinya asas hukum administrasi contrario actus yaitu asas hukum bahwa lembaga yang mengeluarkan izin atau yang memberikan pengesahan adalah lembaga yang seharusnya mempunyai wewenang untuk mencabut atau membatalkannya;

e. Selama ini, pengertian tentang ajaran dan tindakan yang bertentangan dengan pancasila dirumuskan secara sempit yaitu hanya sebatas pada ajaran Atheisme, Marxisme, dan Linisisme, padahal sejarah Indonesia membuktikan bahwa ajaran-ajaran lain yang terdapat dalam bingkai sosial masyarakat juga bisa dan bertentangan dengan Pancasila. Berdasarkan argumentasi tersebut, menjadikan Undang-Undang Nomor 16 Tahun 2017 Tentang Organisasi Kemasyarakatan sebagai payung hukum bagi pemerintah untuk membubarkan organisasi masyarakat yang memiliki potensi bertentangan secara ideologi dengan Pancasila dan UUD NKRI 1945 dalam rangka memberdayakan dan membina organisasi masyarakat agar mampu berkontribusi positif dalam pembangunan nasional. Selain itu, dalam Perpu ormas tersebut juga menambahkan sistem pembubaran berdasarkan asas cotrario actus, yaitu yang memberikan izin dan mengesahkan ormas itu juga diberikan hak untuk mencabut izin ormas yang bersangkutan.

Ditetapkannya Undang-Undang Nomor 16 Tahun 2017 Tentang Penetapan Peraturan Pemerintah Pengganti Undang-Undang Nomor 2 Tahun 2017 Tentang Perubahan Atas Undang-Undang Nomor 17 Tahun 2013 Tentang Organisasi Kemasyarakatan dalam konteks negara Indonesia sebagai negara hukum dan demokratis pada dasarnya dalam rangka pengaturan terhadap organisasi masyarakat yang bertentangan dengan Pancasila dan Undang-Undang Dasar Negara Republik Indonesia Tahun 1945. Namun, dengan diterapkannya Undang-Undang tersebut memunculkan asumsi negatif terhadap kebijakan pemerintah yang cenderung berkarakter ortodoks/konservatif. Hal tersebut tidak dapat dihindari karena dalam kebijakan tersebut beberapa pasal memiliki substansi untuk mencederai prinsip dasar negara hukum dan hak asasi manusia sebagaimana yang diamanatkan dalam Konstitusi. Pengaturan terhadap pembubaran Organisasi masyarakat dalam Undang-Undang Nomor 16 Tahun 2017 Tentang Organisasi Kemasyarakatan terdapat perubahan yang sangat mendasar, yaitu menghilangkan proses peradilan (due process of law) dengan memasukan asas contrario actus. Pengaturan tersebut dinilai mencederai hak kebebasan berserikat dan berkumpul dan prinsip negara hukum. Hak kebebasan berserikat dan berkumpul merupakan salah satu derivasi dari hak-hak sipil dan politik sebagaimana dirumuskan dalam Pasal 20 DUHAM. Dengan pandangan tersebut, pengaturan pembubaran organisasi masyarakat dinilai suatu kebijakan yang inkonstitusional, karena bertentangan dengan Undang-Undang Dasar Negara Republik Indonesia Tahun 1945. Selain itu, pengaturan proses pembubaran organisasi masyarakat tanpa proses peradilan dengan menggunakan kewenangan absolut pemerintah eksekutif, merupakan bukan karakter prinsip negara hukum, melainkan prinsip karakter negara kekuasaan. Oleh karena itu, perlu menjadi evaluasi dan catatan penting bagi penegak hukum dan pemerintah, untuk kiranya memberikan kebijakan yang lebih proporsional demi terhapusnya potensi tindakan kesewenang-wenangan terhadap hak-hak warga negara. 


\section{Daftar Pustaka}

\section{Buku}

Budi, Andhi Setya, dkk, Kedudukan Undang-Undang Keormasan Terhadap Kehidupan Berdemokrasi Di Indonesia. Naskah hukum.

Yuslim. 2015. Hukum Acara Peradilan Tata Usaha Negara. Jakarta: Sinar grafika.

Marzuki, Peter Mahmud. 2009. Penelitian Hukum. Jakarta: Kencana.

Meleong, Lexy. 2003. Metodologi Penelitian Kualitatif. Bandung: CV.Rosda Karya.

MD, Moh. Mahfud. 2018. Politik Hukum di Indonesia. Depok: Rajawali Pers.

Astawa, I Gde Pantja, Suprin Na"a, 2012. Dinamika Hukum dan Ilmu Perundang-Undangan Di Indonesia. Bandung: P.T ALUMNI.

Shapiro, Martin, Stone Sweet, Alec. 2002. on Law, Politics, and Judicializations, New York: Oxford.

Asshiddiqie, Jimly. 2004. Konstitusi dan Konstitusionalisme Indonesia, Jakarta: Konstitusi Press.

Kelsen, Hans, 1949. General Theory of Law. London: Oxford University Press.

Garner, Bryan A., 2010. Black"s Law Dictionary Ninth Edition. St. PaulMinn: West Publishing co.

Reksodiputro, Mardjono. 1994. Hak Asasi Manusia Dalam Peradilan Pidana. Jakarta: Pusat Pelayanan Keadilan dan Pengabdian Hukum.

Budiarjo, Miriam. 2008. Dasar-Dasar Ilmu Politik. Jakarta: PT. Gramedia Pustaka Utama.

Bambang Arwanto, "Perlindungan Hukum Bagi Rakyat Akibat Tindakan Faktual Pemerintah", Jurnal Yuridika, Vol. 31 No. 3 September 2016.

\section{Jurnal}

Jurnal Penelitian Hukum, "Politik Hukum Dan Konstitusionalitas Kewenangan Pembubaran Organisasi Kemasyarakatan, Berbadan Hukum Oleh Pemerintah". No: 30/E/KPT/2018, 446.

Rahmat Efendi Al Amin Siregar, "Due Process of Law dalam Sistem Peradilan Pidana di Indonesia Kaitannya dengan Perlindungan HAM", Jurnal Ilmiah Fitrah, Vol. 1, 2015

Atip Latipulhayat, “Due Process of Law”, Jurnal Hukum Padjajaran, Vol. 4 No. 2, 2017

\section{Makalah Konferensi}

Sudjito, Membaca "Kepentingan Politik" di balik Perpu ormas dan Implikasi sosiologisnya pada masyarakat, makalah dalam seminar nasional: QUO VADIS PERPPU ORMAS, diselenggarakan oleh FH UII, R. Sidang utama Lt. 3.

\section{Perundang-Undangan}

Putusan Mahkamah Konstitusi 6-3-20/PUU-VIII/2010 tentang Pengujian Undang-Undang Nomor 16 Tahun 2004 tentang Kejaksaan Republik Indonesia 